chiếm 40\%[4]. Trong nghiên cứu của tác giả Rajanikanth, tỷ lệ trụ mũi cân đối sau phẫu thuật là 35\%, thấp hơn của chúng tôi, điều này có thể do trong nghiên cứu của tác giả, nhóm khe hở nặng chiếm tỷ lệ cao hơn của chúng tôi [6].

Kết quả chung sau 3 tháng và 6 tháng phẫu thuật đạt loại tốt chiếm 83,33\%: kết quả trung bình chiếm: 16,67\%; Không có bệnh nhân có kết quả kém. Tỷ lệ kết quả tốt sau phẫu thuật của chúng tôi thấp hơn nghiên cứu của Nguyễn Hoàng Minh [4] và Rajanikanth [6] và tương tự nghiên cứu của Nguyễn Văn Minh [8]. Nghiên cứu của Taiwo và cộng sự tại một bệnh viện thực hành tại Nigeria chỉ đạt mức kểt quả tốt sau phẫu thuật là $67,9 \%$ thấp hơn kết quả nghiên cứu của chúng tôi do các đối tượng phầu thuật gồm trẻ có khe hở môi một bên và khe hở hai bền [3].

\section{KẾT LUÂN}

- Phân loại khe hở môi trước phẫu thuật: 58,33\% mức độ nặng, 36,11\% mức độ trung bình, 5,56\% mức độ nhẹ.

- 100\% bệnh nhần không gặp các biến chứng sớm: chảy máu sau mổ, nhiểm trùng vết mổ, bục chỉ vết mổ, tụ máu bầm tím tại chỗ, đầu vạt/vạt bị hoai tử.

- Sau phẫu thuật 3 tháng, 6 tháng: 83,33\% bênh nhân đạt kết quả tốt trong đó: $86,11 \%$ môi trắng cân đối, $100 \%$ nhân trung cân đối, $66,67 \%$ môi đỏ cân đối, $100 \%$ không có lỗ dò và khuyết hổng thứ phát. Tỉ lệ sẹo dãn thẩm mĩ, giấu sẹo tốt sau phẫu thuật 3 tháng là $75 \%, 6$ tháng là $86,11 \%$.

\section{TÀI LIÊU THAM KHẢO}

1. Nguyễn Bắc Hùng (2005), Phẫu thuật tạo hình, Nhà xuất bản Y hoc, Hà Nôii, trang 143-148

2. Adekunle Moses Adetayo, Modupe Olushola Adetayo, Wasiu Lanre Adeyemo et al. (2019) "Unilateral cleft lip: evaluation and comparison of treatment outcome with twosurgical techniques based on qualitative (subject/guardian and professional) assessment" J Korean Assoc Oral Maxillofac Surg 2019;45:141-151

3. Taiwo 0. Abdurrazaq, Adeyemi 0. Micheal, Adeyemo W. Lanre, et la (2013) "Surgical outcome and complications following cleft lip and palate repair in a teaching hospital in Nigeria" African Journal of Paediatric Surgery, OctoberDecember 2013, Vol 10, Issue 4, p345-357

4.Nguyê̂n Hoàng 'Minh (2016) "Kết quả tạo hình khe hở môi một bên toàn bộ bằng phương pháp Millard cải tiến kết hợp tạo hình mũi thì đầu" Kỳ yếu Hội nghị Khoa học - Công nghệ tuổi trẻ các trường Đại học, Cao đẳng Y - Dược Việt Nam lần thứ XVIII năm 2016, tr 268-271.

5. Đăng Hoàng Thơm, Nguyễn Thanh liêm (2013) "Đ́ánh giá kết quả phấu thuât tao hình khe hở môi một bên ở trẻ sơ sinh bằng kỹ thuật Onizuka cải tiển" Tap chí Y học TP Hồ Chí Minh, chuyên đề ngoại nhi, tập 17, số 3 năm 2013, trang 1-7.

6. Rajanikanth B.R., Krishna S.R., Sharma S.M., ete. (2012). Assessment of Deformities of the Up and Nose in Cleft Lip Alveolus and Palate Patients by a Rating Scale. J. Maxiilofac. Oral Surg, 11,38 - 46.

7. Mortier M.A. (1997). Evaluation of the results of cleft lip and palate surgical treatment. Cieft palate - craniofacial journal, 34, 247- 255.

8. Nguyễn Văn Minh (2009). Đánh giá vai trò tạo hinh chữ $Z$ ở trên đường viền da -môi đỏ trong phương pháp Millard mổ khe hở môi một bên toàn bộ. Luận văn tốt nghiệp thạc sỹ, Đại học Y Hà Nội.

\title{
HIỆU QUẢ ĐIỀU TRI NộI NHA TRÊN RĂNG Có SANG THƯƠ'NG QUANH CHÓP CỦA XI-MĂNG TRÁM BÍT ỐNG TỦY NỀN CALCIUM SILICATE
}

\section{TÓM TẮT}

Mục tiêu: Đánh giá mức độ đau (đau tự phát và đau khi ăn nhai) sau trám bít hệ thống ống tủy bằng Xi-măng nền Calcium Silicate tại thời điểm $6 \mathrm{~h}, 12 \mathrm{~h}$, $24 \mathrm{~h}$ và $72 \mathrm{~h}$. Đánh giá kích thước sang thương quanh chóp trên X-quang tại thời điểm ngay sau khi trám bít hệ thống ống tủy, 3 tháng, 6 tháng. Đối tượng và phương pháp nghiên cứu: nghiên cứu báo cáo

*Bệnh viện Quận 1, Tp.HCM

**Đai hoc Y Dước Thành phố Hồ Chí Minh

Chịu trách nhiệm chính: Trân Xuân Vĩnh

Email: vinhdentist@yahoo.com

Ngày nhận bài: 22.2.2021

Ngày phản biên khoa học: 22.3.2021

Ngày duyệt bài: 2.4 .2021

\section{Nguyễn Phan Hoài Mỹ*, Trần Xuân Vĩnh**}

hàng loạt $c a$, thực hiện trên 16 răng một chân có bệnh lý sang thương quanh chóp, được trám bít hệ thống ống tủy bằng Xi-măng nền Calcium Silicate của 15 bệnh nhân (trên 18 tuổi) tại Bệnh viện Quận 1 trong thời gian từ tháng 07/2020 đến 03/2021. Kết quả: Đối tượng nghiên cứu có độ tuổi trung bình là 50,6 tuổi, nữ chiếm $43,7 \%$. Có $37,5 \%$ bênh nhân có áp-xe quanh chóp răng, sau 3 tháng $100 \%$ các răng không còn áp-xe, không còn dấu chứng lâm sàng. Mức độ đau tự phát và đau khi ăn nhai trung bình của bênh nhân cao nhất là ngay sau khi trám bít hê thống ống tủy theo thang đo VAS (3,8 điểm và 3,9 điểm), sau đó giảm dần ở các thời điểm sau đó 6 giơo, 12 giớ 24 giờ và thấp nhất là sau 72 giờ trám bít hệ thống hệ thống ống tủy ( 0 điểm). Diện tích trung bình vùng thấu quang đo bằng phần mềm ImageJ và đánh giá tình trạng sang thương quanh chóp trên X-quang theo 
chỉ số PAI ngay tại thời điểm ngay sau khi trám bít hệ thống ống tủy cao hơn so với 3 tháng, 6 tháng và tại thời điểm 3 tháng cao hơn 6 tháng $(p<0,05)$. Kết Iuân: Kết quả nghiên cứu cho thấy hiệu quả của xi mẳng trám bít ống tủy nền calcium silicat trong điều trị sang thương quanh chóp mạn: chữa lành hoăc cải thiện tình trạng phá hủy xương quanh chóp, có dấu hiệu tái tao xương trên X-quang.

Tư khóa: sang thương quanh chóp, xi-măng, calcium silicate

\section{SUMMARY \\ EFFECT OF CALCIUM SILICATE-BASED ROOT CANAL SEALER ON TEETH WITH PERIAPICAL LESIONS}

Objectives: To assess of postoperative pain level (spontaneous pain and pain when chewing) by visual analogue scale at 6, 12, 24 and 72 hours after filling with calcium silicate-based root canal sealer. To evaluate the size of periapical lesions on X-rays at the time after filling of the canal system, 3 months, 6 months. Methods: The study reported a series of cases, performed on 16 teeth with single root and periapical lesions, were filled with calcium silicate-based root canal sealer of 15 patients (over 18 years old) who came for oral examination and treatment at District 1 Hospital in the period from 07/2020 to 03/2021. Results: The mean age of the study participants was 50.6 years, female accounted for $43.7 \%$. There were $37.5 \%$ of patients with abscesses around the tooth apex. After 3 months, $100 \%$ of teeth had no abscesses, no more clinical signs. The highest level of spontaneous pain and chewing pain of the patient was immediately after root canal obturation on the VAS scale (3.8 points and 3.9 points), then gradually decreased at different times. After 6 hours, 12 hours, 24 hours and the lowest is after 72 hours of sealing the canal system ( 0 point). The average area of the radiographic were measured by ImageJ software and the peri-apical lesion size on the radiograph according to the PAI index after root canal obturation was higher than 3 months, 6 months and at 3 months it was higher than 6 months ( $p$ $<0.05)$. Conclusion: The results showed that the effectiveness of calcium silicate-containing root canal sealer in the treatment of chronic apical periodontitis: healing or improvement of radiographic conditions of periapical bone destruction with X-ray signs of bone regeneration.

Key words: periapical lesion, sealer, calcium silicate

\section{I. ĐĂT VẤN ĐỀ}

Điều trị nội nha nhằm bảo tồn răng là một thách thức lớn trong nha khoa. Nhiều yếu tố góp phần thành công trong thực hành nội nha bao gồm tạo dạng làm sạch, khử khuẩn, trám bít hệ thống ống tủy chân răng và sau cùng là tái tạo thân răng đây đủ, đúng lúc. Trong đó, giai đoạn trám bít hệ thống ống tủy đóng vai trò rất quan trọng trong sự thành công của điêu trị nội nha. Hệ thống ống tủy được trám bít hoàn toàn đảm bảo ngăn ngừa các vi khuẩn còn sót và các độc tô của chúng. Với sự tiến bộ của khoa học hiện nay, nhiều kỹ thuật cũng như vật liệu được cải tiến góp phần thành công cho việc điều trị nội nha.

Trong nhiều thập kỷ, Gutta-Percha đã được xem là vâtt liêu chính có thể thích nghi và tương thích nhất để bít kín ống tủy. Mặt khác, một số xi măng được sử dụng cùng với gutta-percha với những đặc tính cơ học, sinh học khác nhau, tạo thành khối đồng nhất khít kín hệ thống ống tủy, ngăn chặn sự hình thành vi kẽ, ngăn cản sự tái viêm nhiếm và ảnh hưởng đến kết quả điêu trị nội nha.

Các xi măng trám bít ông tủy được phần loại dựa theo thành phần hóa học chính: Oxyt kẽm Eugenol, Calcium Hydroxide, Glass-Ionomer, Silicone và nhựa Epoxy hoặc Methacrylate. Những năm gần đây, xi măng có chất căn bản là Calcium Silicate chứa hỗn hợp khoáng trioxide đã được giới thiêu và sử dung phổ biến trong nội nha. Ưu điểm nổi bật của vật liệu này là nó có hoạt tính sinh học cao, khả năng bám dính cao cùng với phóng thích Calcium Hydroxide sau khi đông, hình thành pha Calcium Photphate khi tiếp xúc với dung dịch sinh lý, ít gây độc trên tế bào dây chằng nha chu, kích thích các yếu tố tăng trưởng tạo máu và tạo xương [2] giúp chữa lành thương trong trường hợp viêm quanh chóp răng [8].

Trên thế giới, nhiều nghiên cứu vi kẽ in-vitro đã được thực hiện nhằm đánh giá hiệu quả trám bít ống tủy và hoạt tính tương hợp sinh học, kích thích các yếu tố tăng trưởng tạo máu, tạo xương của xi măng Calcium Silicate [1].

Tại Việt Nam cũng có các nghiên cứu về hiệu quả kháng khuẩn và độc tính với tế bào và hiệu quả trám bít ống tủy chân răng của xi măng mới này với loại vật liệu khác (AH 26). Với những kết quả nghiển cứu in vitro về xi măng Calcium Silicate rất khả quan cho thấy hiệu quả bít kín ống tủy sau 30 ngày, có tính tương hợp sinh học, khả năng kích thích tế bào xương người tăng sinh. Đây là một trong những tiêu chuẩn góp phần thành công cho điều trị nội nha. Tuy nhiên, các nghiên cứu về hiệu quả điều trị trên lâm sàng của xi măng Calcium Silicate còn rất ít.

Mục tiêu: Đánh giá mức độ đau (đau tự phát và đau khi ăn nhai) sau trám bít hệ thống ông tưy bằng xi măng nên calcium silicate tại thời điểm 6h, 12h, 24h và $72 h$ của bệnh nhần đến khám và điều trị răng miệng tại Bệnh viện Quận 1. Tp.HCM.

Đánh giá kích thước sang thương quanh chóp trên X-quang tại thời điểm ngay sau khi trám bít hệ thống ống từy, 3 tháng, 6 tháng.

\section{II. ĐỐI TƯƠ'NG VÀ PHƯƠNG PHÁP NGHIÊN CỨU Thiết kế nghiên cứu: Báo cáo loạt ca}


Đối tượng nghiên cứu: các răng một chân có bệnh lý sang thương quanh chóp răng của bệnh nhân đến khám và điều trị răng miệng tại Bệnh viện Quận 1.

Cỡ mẫu và phương pháp nghiên cúu: chọn toàn bộ 16 răng một chân của 15 bệnh nhân đến khám và điều trị răng miệng tại Bệnh viện Quận 1 có bệnh lý sang thương quanh chóp răng trong thời gian từ tháng 07/2020 đến 03/2021. Câc răng được điêu trị nội nha theo quy trình mở tủy, sửa soạn ống tủy bằng trâm xoay máy, bơm rửa với EDTA $17 \%$, Sodium Hypochlorite 3\%. Băng thuốc với Canxihydroxite trong 1 đến 2 tuần và trám bít hệ thống ống tủy bằng kỹ thuật một côn với xi măng trám bít BioRoot $^{T M}$ RCS (Septodont, Saint-Maur-desFossés, Pháp). Các bệnh nhân trở lại tái khám sau 1 tuần, 3 tháng, 6 tháng.

Tiêu chuẩn lựa chọn: bệnh nhân trên 18 tuổi có bệnh lý sang thương quanh chóp răng (đường kính sang thương $\leq 10 \mathrm{~mm}$ ).

Tiêu chuẩn loại trừ: Phụ nữ mang thai hoăc có ý định có thai. Những người có bệnh lý toàn thân phải dùng kháng sinh phòng ngừa trong các thủ thuật nha khoa. Người bị viêm mô tế bào hoặc răng bị áp-xe quanh chóp cấp hoặc viêm quanh chóp cấp, các răng bị canxi hóa ống tủy, các trường hợp nội tiêu hoặc ngoại tiêu chân rang.

Phương pháp đánh giá trong nghiên cứu

- Đánh giá đau: theo thang điểm VAS. Bệnh nhân cho điểm từ 0-10 (với 0 là không đau tằng dần lên đến 10 là đau dữ dội) tại thời điểm 6 giờ, 12 giờ, 24 giờ, 72 giờ sau khi điêu trị trám bít ống tủy, ghi nhận đau tự phát và đau khi ăn nhai.

Đánh giá theo chỉ số PAI: hệ thống PAI tính điểm 1 đến 5 là có bệnh lý viêm quanh chóp gồm 1-Cấu trúc quanh chóp bình thường, 2- Có thay đổi nhỏ ở cấu trúc xương, 3-Có mất xương mức độ ít, 4-Có sang thương thấu quang rõ, 5Viêm quanh chóp trầm trọng.

- Phần mềm Imagej (Version 1.52 tháng 2019) để đánh giá sự lành thương bằng cách đo diện tích vùng thấu quang và so sánh giữa các lần tái khám.

Nhập liệu và xử lý số liệu: nhập liệu bằng Excel 2010, phân tích bằng SPSS 20.0. Thống kê mô tả dùng tấn số và tỉ lệ \%, trung bình, độ lệch chuẩn, giá trị nhỏ nhất, lớn nhất. Các phép kiểm thống kê sử dụng là T-test bắt cặp, Mann Whitney với mức ý nghĩa $\mathrm{p}<0,05$.

Đạo đức nghiên cứu: nghiên cứu đã được thông qua Hội đồng Đạo Đức của Đại Học Y Dược Tp.HCM theo quyết định số 453/HĐĐĐ-
ĐHYD ngày 21/7/2020. Đối tượng tham gia nghiên cứu đều tình nguyện và được thông tin rõ ràng về nghiên cứu và được ký phiếu đồng ý tham gia nghiên cứu.

\section{KẾT QUẢ NGHIÊN CỨU}

Đặc điểm của đối tượng nghiên cứu. Đối tượng nghiên cứu có độ tuổi trung bình là 50,6 tuổi, nữ chiếm $43,7 \%$. có $37,5 \%$ bệnh nhân có abces tại sang thương quanh chóp răng, sau 3 tháng $100 \%$ các răng không còn abces.

Mức độ đau tự phát và đau khi ăn nhai tại các thời điểm nghiên cứu

Mức đồ đau tự phát tại các thời điểm nghiên cứu

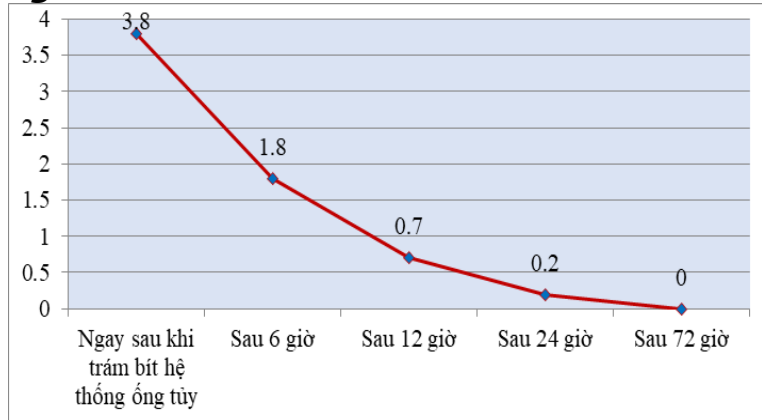

Biếu đồ 1. Mức độ đau tự phát của bệnh nhân tại các thời điểm nghiên cứu theo thang đo VAS $(n=16)$.

Mức độ đau tự phát trung bình cao nhất tại thời điểm ngay sau khi trám bít hệ thống ống tủy theo thang đo VAS ( 3,8 điểm), sau đó giảm dân ở các thời điểm sau đó 6 giờ, 12 giờ, 24 giờ và không còn đau sau 72 giờ trám bít hệ thống hệ thống ống tủy ( 0 điểm).

Mức độ đau khi ăn nhai tại các thời điểm nghiên cứu

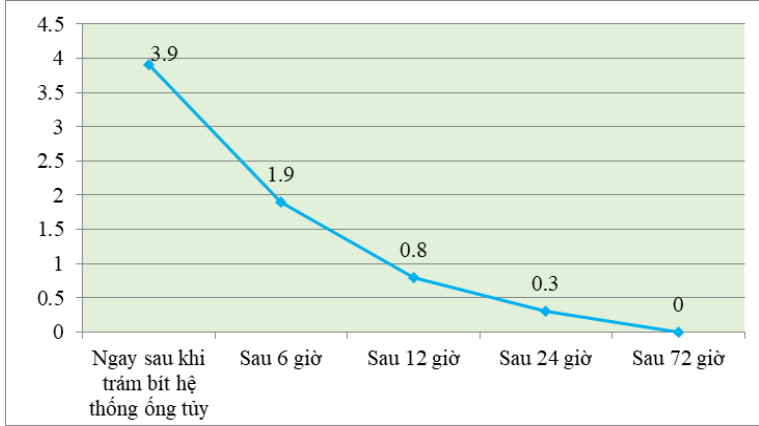

Biểu đồ 2. Mức độ đau khi ăn nhai của bệnh nhân tại các thời điểm nghiên cứu theo thang do VAS $(n=16)$

Mức độ đau khi ăn nhai trung cao nhất tại thời điểm ngay sau khi trám bít hệ thống ống tủy (3,9 điểm), sau đó giảm dần ở các thời điểm sau đó 6 giờ, 12 giờ, 24 giờ và thấp nhất là sau 72 
giờ trám bít hệ thống ống tủy ( 0 điểm).

Đánh giá sang thương quanh chóp răng theo PAI trên X-quang tại thời điểm nghiên cứu

Bảng 1: So sánh sang thương quanh chóp theo PAI trên X-quang tại thời điểm ngay sau khi trám bít hệ thống ống tủy với sau đó 3 tháng, 6 tháng $(n=16)$

\begin{tabular}{|c|c|c|c|}
\hline $\begin{array}{c}\text { Kích thước sang } \\
\text { thương theo PAI }\end{array}$ & $\begin{array}{c}\text { TB } \pm \\
\text { ĐLC }\end{array}$ & $\begin{array}{c}\text { NN- } \\
\text { LN }\end{array}$ & p* \\
\hline $\begin{array}{c}\text { Ngay sau khi trám bít } \\
\text { hệ thống ống tủy }\end{array}$ & $\begin{array}{c}4,6 \pm \\
0,5\end{array}$ & $4-5$ & \\
\hline $\begin{array}{c}\text { Sau trám bít hê thống } \\
\text { ống tủy 3 tháng }\end{array}$ & $\begin{array}{c}3,1 \pm \\
0,5\end{array}$ & $2-4$ & $<0,001$ \\
\hline $\begin{array}{c}\text { Sau trám bít hê thống } \\
\text { ống tủy 6 tháng }\end{array}$ & $\begin{array}{c}2,4 \pm \\
0,8\end{array}$ & $1-4$ & $<0,001$ \\
\hline
\end{tabular}

*Kiểm định ttest bắt cặp

Có sự khác biết có ý nghĩa thống kê về tình trang sang thương theo PAI trên X-quang tại thời điểm ngay sau khi trám bít hệ thống ống tủy và sau đó 3 tháng, 6 tháng. Trong đó, kích thước trung bình ngay tại thời điểm ngay sau khi trám bít hệ thống ống tủy cao hơn so với 3 tháng, 6 tháng sau đó (với $p<0,05$ ).

Báng 2. So sánh sang thương theo PAI trên X-quang tại thời điểm 3 tháng với 6 tháng sau khi trám bít hệ thống ống tủy $(n=16)$

\begin{tabular}{|c|c|c|c|}
$\begin{array}{c}\text { Tình trạng sang } \\
\text { thương theo PAI }\end{array}$ & $\begin{array}{c}\text { TB } \pm \\
\text { DLC }\end{array}$ & $\begin{array}{c}\mathbf{N N} \text { : } \\
\text { LN }\end{array}$ & p* \\
\hline $\begin{array}{c}\text { Sau trám bít hê̂ thống } \\
\text { ống tủy } 3 \text { tháng }\end{array}$ & $\begin{array}{c}3,1 \pm \\
0,5\end{array}$ & $2-4$ & \multirow{2}{*}{0,001} \\
\cline { 1 - 3 } $\begin{array}{c}\text { Sau trám bít hế thống } \\
\text { ống tủy } 6 \text { tháng }\end{array}$ & $\begin{array}{c}2,4 \pm \\
0,8\end{array}$ & $1-4$ & \\
\hline
\end{tabular}

*Kiếm định ttest bắt cặp

Có sự khác biết có ý nghĩa thống kê về tình trang sang thương theo PAI trên X-quang tại thời điểm 3 tháng so với 6 tháng sau khi trám bít hệ thống ống tủy. Trong đó, chỉ số PAI sau 3 tháng cao hơn sau 6 tháng (với $\mathrm{p}<0,05$ ).
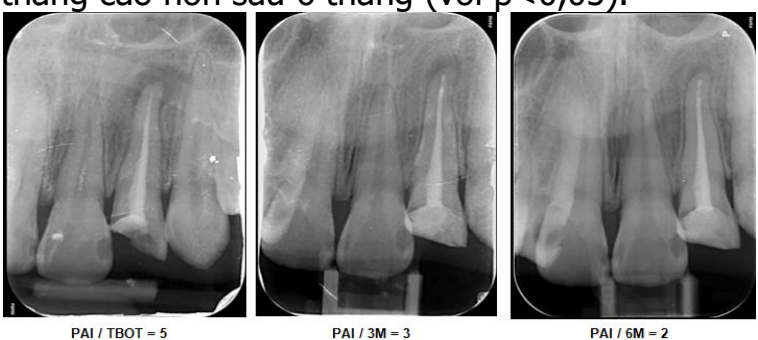

Hình 1: Sang thương quanh chóp theo PAI giảm sau 3 tháng, 6 tháng

Bảng 3: Đánh giá diên tích sang thương quanh chóp trên $X$-quang tại thời điêm ngay sau khi trám bít hệ thống ống tủy và sau đó 3 tháng, 6 tháng $(n=16)$

\begin{tabular}{|c|c|c|c|}
\hline $\begin{array}{l}\text { Kích thước sang } \\
\text { thương quanh chóp } \\
\text { trên } X \text { quang }\end{array}$ & $\begin{array}{l}\text { TB士 } \\
\text { ĐLC }\end{array}$ & $\begin{array}{l}\text { NN- } \\
\text { LN }\end{array}$ & p* \\
\hline $\begin{array}{l}\text { Ngay sau khi trám bít } \\
\text { hệ thống ống tủy }\end{array}$ & $\begin{array}{c}20,0 \pm \\
14,0\end{array}$ & $\begin{array}{l}4,1- \\
60,7\end{array}$ & \\
\hline $\begin{array}{l}\text { Sau trám bít hệ thống } \\
\text { ống tủy } 3 \text { tháng }\end{array}$ & $\begin{array}{c}12,4 \pm \\
11,5\end{array}$ & $\begin{array}{l}1,1- \\
49,6\end{array}$ & $<0,001$ \\
\hline $\begin{array}{l}\text { Sau trám bít hệ thống } \\
\text { ống tủy } 6 \text { tháng }\end{array}$ & $\begin{array}{c}8,1 \pm \\
9,6\end{array}$ & $\begin{array}{l}0,8- \\
41,2\end{array}$ & $<0,001$ \\
\hline
\end{tabular}

*Kiểm đinh Man Whitney

Có sự khác biệt có ý nghĩa thống kê về diện tích sang thương quanh chóp trên X-quang tại thời điểm ngay sau khi trám bít hệ thống ống tủy và sau đó 3 tháng giảm $38 \%$, sau 6 tháng giảm gần $60 \%$ so với kích thước ban đầu. Trong đó, diện tích trung bình ngay tại thời điểm ngay sau khi trám bít hệ thống ống tủy cao hơn so với 3 tháng và 6 tháng sau đó $($ với $p<0,05)$.

Bảng 4. Đánh giá diện tích sang thương quanh chóp trên $X$-quang tại thời điểm 3 tháng so với 6 tháng sau khi trám bít hệ thông ống tủy $(n=16)$

\begin{tabular}{|c|c|c|c|}
\hline $\begin{array}{l}\text { Kích thước sang } \\
\text { thương quanh chóp } \\
\text { trên X quang }\end{array}$ & $\begin{array}{l}\text { TB } \pm \\
\text { ĐLC }\end{array}$ & $\begin{array}{l}\text { NN- } \\
\text { LN }\end{array}$ & p* \\
\hline $\begin{array}{l}\text { Sau trám bít hệ thống } \\
\text { ống tủy } 3 \text { tháng }\end{array}$ & $\begin{array}{l}12,4 \pm \\
11,5\end{array}$ & & \\
\hline Sau trám bít hệ thống & $8,1 \pm$ & $0,8-$ & \\
\hline
\end{tabular}

*Kiểm định Man Whitney

Có sự khác biết có ý nghĩa thống kê về diện tích sang thương quanh chóp trên X-quang tại thời điểm 3 tháng so với 6 tháng sau khi ngay trám bít hệ thống ống tủy. Trong đó, diện tích sang thương trung bình sau 3 tháng cao hơn so với 6 tháng (với $p<0,05$ ).
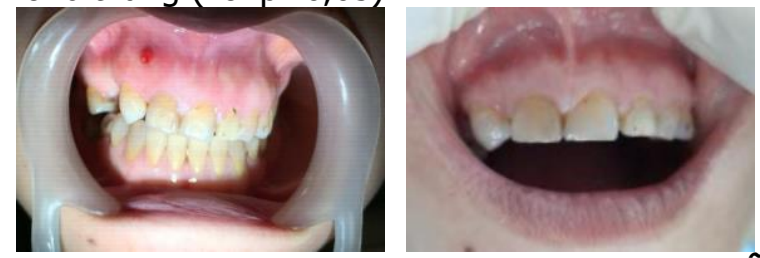

Hình 2: Tái khám sau 3 tháng không còn lố
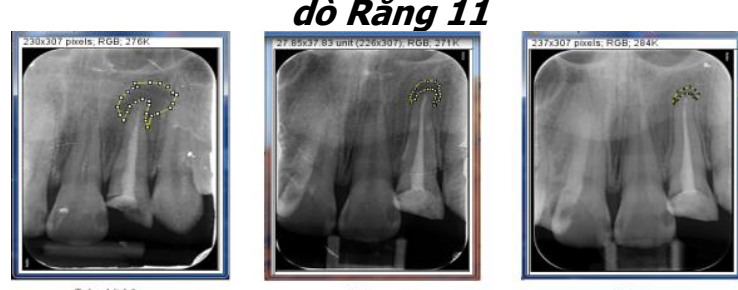

Tram bith
Hình 3: Diện tích thâu quang giảm diàn sau 3 tháng, 6 tháng (đo bằng ImageJ) 


\section{BÀN LUÂN}

Đối tượng nghiên cứu có độ tuổi trung bình là 50,6 tuổi; trong đó người nhỏ nhất tham gia nghiên cứu là 19 tuổi và người lớn nhất là 75 tuổi. Tỉ lệ nữ trong nghiên cứu lá $43,7 \% ; 37,5 \%$ bệnh nhẩn có lỗ dò nướu tại sang thương quanh chóp răng, sau 3 tháng $100 \%$ các răng không còn lỗ dò.

Xi măng BioRoot RCS sử dụng trong nghiên cứu bao gồm một loại bột và một chất lỏng là chất trám bít ống tủy mới dựa trên Tricalcium silicate được giới thiệu gần đây. Thành phần bột bao gồm Tricalcium silicat, zirconium dioxit, và povidone, và chất lỏng bao gồm nước, calcium chloride và polycarboxylate. BioRoot RCS có thời gian làm việc tối thiểu là 10 phút và thời gian đông kết tối đa 4 giờ. Xi măng bít ống tủy nền silicate này ít độc hại lên các tế bào dây chằng nha chu hơn và phóng thích yếu tố tăng trưởng tạo mạch và sinh xương[7]. BioRoot RCS so với xi măng trám bít ống tủy hiện đại (AHPlus, Acroseal, EndoRez, RealSeal SE, Hybrid Root SEAL, RootSP và MTA Fillapex) có mức độc tính tế bào và độc tính di truyền thấp hơn. Sự bít kín của BioRoot RCS kết hợp với gutta-percha có thể so sánh với AHPlus[6].

Đau sau điều trị nội nha phản ánh sự kích hoạt phản ứng viêm cục bộ ở các mô quanh răng, được cho rằng có liên quan đến thành phần chất trám bít và các phương pháp bịt kín ống tủy[3]. Xi măng nền Calcium silicat cho thây các đặc tính lý hóa và sinh học tốt, cho kết quả tương tự hoặc tốt hơn so với chất trám nội nha thông thường khi được quan sát trong các nghiên cứu trên động vật in vitro và in vivo[8].

Trong nghiên cứu này, mức độ đau tự phát trung bình của bệnh nhân có bệnh lý sang thương quanh chóp răng cao nhất tại thời điểm ngay sau khi trám bít hê thống ống tủy theo thang đo VAS sau đó giảm dần ở các thời điểm sau đó 6 giờ, 12 giờ, 24 giờ và hết đau sau 72 giờ trám bít hệ thống hệ thống ống tủy. Mức độ đau khi ăn nhai trung bình của bệnh nhân cao nhất tại thời điểm ngay sau khi trám bít hệ thống ống tủy sau đó giảm dân ở các thời điểm sau đó 6 giờ, 12 giờ, 24 giờ và không còn đau sau 72 giờ trám bít hệ thống ông tủy. Có sư khác biết có ý nghĩa thống kê về diện tích vùng thấu quang theo ImageJ trên X-quang tại thời điểm ngay sau khi trám bít hệ thống ống tủy, sau 3 tháng, 6 tháng. Trong đó, kích thước trung bình ngay tại thời điểm ngay sau khi trám bít hệ thống ống tủy cao hơn so với 3 tháng, 6 tháng sau đó.

Nghiên cứu này cũng phù hợp với kết quả nghiên cứu của Gadzhula (2016) cho thấy sau một năm đánh giá BioRoot RCS trám bít ông tủy trong điều trị viêm quanh chóp mãn có $54,55 \%$ bênh nhân đã chữa lành xương hoàn toàn, trong đó $27,27 \%$ trường hợp phá hủy xương trâm trọng giảm 1/2 hoặc hơn kích thước ban đầu, 18,18\% có tiêu xương giảm ít hơn 1/2; Nghiên cứu đã chứng minh hiệu quả chữa lành hoàn toàn hoặc cải thiện tình trạng tiêu xương quanh quanh chóp, có dấu hiệu tái tạo xương trên XQuang[4].

Sau 6 tháng theo dõi, răng được đánh giá lành thương thành công hoặc thất bại dựa trên các dấu chứng lâm sàng và chụp $X$ quang. Kết quả nghiên cứu cho tháy 16 răng có kết quả thành công $100 \%$. Kết quả này cũng tương tự với nghiên cứu của Kawther và cộng sự (2021) với kết quả sau 6 tháng theo dõi, tỳ lệ thành công là $100 \%$, với $57,1 \%$ được xác định là đã lành thương và $42,8 \%$ đước xác định là đang lành thương. Tất cả các điểm PAI giảm so với tình trạng ban đầu [5].

\section{KẾT LUÂN}

Kết quả nghiên cứu cho thây hiệu quả của xi măng trám bít trên nền calcium silicat trong điều trị nội nha ở răng có sang thương quanh chóp mạn tính qua các dấu chứng lâm sàng như sau 1 tuần, bệnh nhân không còn đau tự phát hay đau khi kích thích, Î̃̂ dò ngoài nướu không còn sau 3 tháng, chỉ số PAI giảm, diện tích vùng sang thương giảm sau 3 tháng, sau 6 tháng và giảm gần $60 \%$ so với kích thước ban đầu.

\section{TÀI LIẸU THAM KHẢO}

1. Lý Nguyễn Bảo Khánh (2017) Hiệu quả trám bít ông tủy chân răng của xi măng Calcium Silicate: nghiên cứu In Vitro, Luân văn thạc sĩ y học, Đại học Y Dược Thành Phố Hồ Chí Minhi,

2. Vổ Thị Thủy Tiên (2017) Hiệu quả kháng khuẩn và đốc tính với tế bào xương của xi măng trám bít ông tủy BioRoot RCS: nghiên cứu In Vitro, Luận văn thạc sĩ y học, Đại học y dược Thành Phố Hî̀ Chí Minh,

3. Atav Ates A, Dumani A, Yoldas $O$, Unal $I$ (2019) "Post-obturation pain following the use of carrier-based system with $\mathrm{AH}$ Plus or iRoot SP sealers: a randomized controlled clinical trial". Clin Oral Investig, 23 (7), 3053-3061.

4. Gadzhula NG (2016) "Clinical Effectiveness of Treatment The Patients With Chronic Apical Periodontitis". International Journal of Medicine and Medical Research, volume 2 (Issue 2), p. 30-33.

5. Kawther Bel Haj Salah, Sabra Jaâfoura, Mahdi tlili, Marwa Ben Ameur, Saida Sahtout1 (2021) "Outcome of Root Canal Treatment of Necrotic Teeth with Apical Periodontitis Filled with a Bioceramic-Based Sealer". International Journal of Dentistry, 2021, 1-8.

6. PrzemysBaw Reszka, Alicja Nowicka, Mariusz Lipski, WBodzimierz Dura, Agnieszka 
Drofdzik, and KrzysztofWofniak (2016) "A Comparative Chemical Study of Calcium SilicateContaining and Epoxy Resin-Based Root Canal Sealers". elsevierhealth,

7. Sasha Dimitrova-Nakova, Emel Uzunoglua, Hector Ardila-Osorioa, Anne Baudrya, Gilles Richardb, Odile Kellermanna, Michel
Goldberga (2015) "In vitro bioactivity of BiorootTM RCS, via A4 mouse pulpal stem cells".

8. Silva Almeida LH, Moraes RR, Morgental RD, Pappen FG (2017) "Are Premixed Calcium Silicate-based Endodontic Sealers Comparable to Conventional Materials? A Systematic Review of In Vitro Studies". J Endod, 43 (4), 527-535.

\title{
THỰC TRANG TIẾP THU KIẾN THỨC MODULE HỆ CƠ QUAN CỦA SINH VIÊN NĂM THỨ HAI CHƯƠNG TRÌNH ĐỔI MỚI NGÀNH Y TẠI TRƯỜNG ĐẠI HỌC Y DƯỢC THÁI NGUYÊN
}

\author{
Nguyễn Thị Bình ${ }^{1}$, Trịnh Xuân Đàn ${ }^{1}$, Nguyễn Thị Sinh ${ }^{1}$, \\ Hoàng Thị Lệ Chi ${ }^{1}$, Đoàn Thị Nguyệt Linh ${ }^{1}$.
}

\section{TÓM TẮT}

Mục tiêu: Đánh giá thực trạng tiếp thu kiến thức Module hệ cơ quan của sinh viên năm hai chương trình đổi mới ngành y khoa tại trường Đại học $Y$ Dược Thái Nguyên. Đối tượng và phương pháp: Mô tả cắt ngang, nghiên cưư định lượng kết hợp định tính tất cả sinh viến y khoa năm thứ 2 sau khi hoàn thành 6 module hệ cơ quan theo chương trình đổi mới ngành y khoa. Kết quả: Qua khảo sát 343 SV: 100\% sinh viên truy cập vào khóa học trên hệ thống Elearning, 86\% sinh viên truy cập elearning đọc đề cương chi tiết, hướng dẫn học tập, lịch học trước khi bắt đâu học mối module; $70 \tilde{\tilde{x}}-80 \%$ sinh viên truy cập elearning xem bài giảng mấu, ca lâm sàng, tài liệu tham khẳo. Tỷ lệ sinh viên chủ động chuẩn bị bài trước mỗi buối hoc theo đúng hướng dẫn họ tâp chiếm 70,3\%; sinh viên tham gia thảo luận nhóm chiếm 74,9\%; tỉ lê sinh viên trả lời được các câu hỏi trong giờ thảo luận ca lâm sàng là $51,3 \%$. Kết quả học tập các module của sinh viên: $97 \%$ sinh viên đạt (điểm > 4,0), chỉ có $3 \%$ số sinh viên không đạt (điểm $<4,0)$ và chiếm tỉ lệ cao nhất là ở mức trung bình $48,7 \%$, số sinh viên giỏi chiếm $4 \%$ và sinh viên kém chiếm 3,05\%. Trong 6 module thì module tiết niệu có số sinh viên đạt kết quả khá là cao nhất 149 sinh viên chiếm $37 \%$ và chỉ có 2 sinh viên là có kết quả kém. Số sinh viên đạt xuất sắc ( 5 sinh viên) và giỏi (67 sinh viên) cũng chiếm tỉ lệ cao nhất. Kết luận: Phương pháp giảng dạy tích cực/ lồng ghép các kiến thức y học cớ sở và lâm sàng đã thúc đây được sự chủ động cững như sự hứng thú hơn của sinh viên trong quá trình tiếp thu các kiến thức các môn tiền lâm sàng. Vì vậy, phương pháp giảng dạy đổi mới này có thể thay thế phương pháp giảng dạy truyền thống cho đối tượng sinh viên y khoa năm thứ 2 nhưng cần có sự điều chỉnh cho hợp lý để nâng cao chất lượng đào tạo, đạt được chuẩn đầu ra của nhà trường.

${ }^{1}$ Trường Đại hoc Y Dược Thái Nguyên

Chịu trách nhiệm chính: Nguyễn Thị Bình

Email:nguyenbinhydtn@gmail.com

Ngày nhận bài: 23/2/2021

Ngày phản biên khoa hoc: 9/3/2021

Ngày duyệt bài: 1/4/2021
Tư khóa: Hệ thống module, lồng ghép, học tập dựa trên vấn đề.

\section{SUMMARY \\ THE REALITY ACQUIRE KNOWLEDGE ORGAN SYSTEM MODULES OF THE $2^{\text {ND }}$ STUDENTS STUDY UNDER MEDICAL INDUSTRY INNOVATION PROGRAM AT THAI NGUYEN UNIVERSITY OF MEDICINE AND PHARMACY}

Objectives: To evaluate the reality acquire knowledge organ system modules of the $2^{\text {nd }}$ students study under medical industry innovation program at thai nguyen university of medicine and pharmacy. Subjects and methods: A cross-sectional study, quantitative study combined qualitative all the $2^{\text {nd }}$ medical students when they finished 6 organ system modules under the innovation program. Research results: Through a survey of 343 students: $100 \%$ of students access the course on Elearning system; $86 \%$ of students accessing Elearning read the detailed outline, study guides, study schedule before the start of each module; $70-80 \%$ of students accessing elearning view sample lectures, clinical cases and reference materials. Students actively prepare lesson according to the right instructions occupy 70,3\%; students participate in discussion groups accounted for 74,9\%; $51,3 \%$ of students answering questions during clinical case discussion. The result of the study module students: $97 \%$ of students passed (mark $>4.0$ ) only $3 \%$ of students failed (mark<4.0) and accounting for the highest percentage is at an average of $48.7 \%$; good student of $4 \%$ and accounted for $3.05 \%$ poor students. Among the 6 modules, the urinary module has the highest number of students with quite results 149 students, accounting for $37 \%$ and only 2 students had poor results. The number of excellent students ( 5 students) and good students (67 students) also accounted for the highest percentage. Conclusion: Integrated modular medical curriculum between basic and clinical medical knowledge has promoted the initiative as well as more excitement of students in the process of acquiring pre-clinical knowledge. So, this teaching method can replace the traditional system for 